\title{
Genome-Wide Mining, Characterization and Development of miRNA-SSRs in Arabidopsis thaliana
}

\author{
Anuj Kumar ${ }^{1,2}$, Aditi Chauhan ${ }^{1}$, Mansi Sharma ${ }^{2}$, Sai Kumar Kompelli ${ }^{3}$, Vijay Gahlaut ${ }^{4}$, \\ Johny Ijaq ${ }^{2}$, Krishna Pal Singh ${ }^{1}$, MNV Prasad Gajula ${ }^{5 *}$, Prashanth Suravajhala ${ }^{3,6,7}$, Harindra \\ Singh Balyan ${ }^{3}$, and Pushpendra Kumar Gupta ${ }^{3}$
}

1. Advance Centre for Computational and Applied Biotechnology, Uttarakhand Council for Biotechnology (UCB), Dehradun-248007, India

2. Bioclues.org, Kukatpally, Hyderabad 500072, Telangana, India

3. ICMR-ICPO (Institute of Cytology and Preventive Oncology), NOIDA, I-7, Sec-39, Uttar Pradesh

4.Molecular Biology Laboratory, Department of Genetics \& Plant Breeding, Ch. Charan Singh University, Meerut-250004, India

4. Institute of Biotechnology, PJTSAU, Rajendra Nagar, Hyderabad-500030, India

5. Bioinformatics Organization, 28 Pope st, Hudson, MA 01749, USA

6. Department of Biotechnology and Bioinformatics, Birla Institute of Scientific Research, Statue Circle, 302001, RJ, India

*Corresponding authors: email2gajula@gmail.com

\section{Abstract}

Simple Sequence Repeats (SSRs), also known as microsatellites are short tandem repeats of DNA sequences that are 1-6 bp long. In plants, SSRs serve as a source of important class of molecular markers because of their hypervariabile and co-dominant nature, making them useful both for the genetic studies and marker-assisted breeding. The SSRs are widespread throughout the genome of an organism, so that a large number of SSR datasets are available, most of them from either protein-coding regions or untranslated regions. It is only recently, that their occurrence within microRNAs (miRNA) genes has received attention. As is widely known, miRNA themselves are a class of non-coding RNAs (ncRNAs) with varying length of 19-22 nucleotides (nts), which play an important role in regulating gene expression in plants under different biotic and abiotic stresses. In this communication, we describe the results of a study, where miRNA-SSRs in full length pre-miRNA sequences of Arabidopsis thaliana were mined. The sequences were retrieved by annotations available at EnsemblPlants using BatchPrimer3 server with miRNA-SSR flanking primers found to be well distributed. Our analysis shows that miRNA-SSRs are relatively rare in protein-coding regions but abundant in non-coding region. All the observed 147 di-, tri-, tetra-, penta- and hexanucleotide SSRs were located in non-coding regions of all the 5 chromosomes of A. thaliana. While we confirm that miRNA-SSRs were commonly spread across the full length pre-miRNAs, we 
envisage that such studies would allow us to identify newly discovered markers for breeding studies.

Keywords: MicroRNA, miRNA-SSRs, Genome-wide identification studies, noncoding RNAs, gene expression

\section{Introduction}

MicroRNAs (miRNA) represent a class of non-coding RNA (ncRNA) with varying length of 19-22 nucleotides (nts) (Bartel, 2004). These miRNAs are endogenous in origin, and are found to play a major role in regulating the gene expressions in plants, fungi and animals, with bulk of the sequences linked to transcription factors (Bartel and Bartel, 2003). The miRNA are involved regulation of genes implicated in different processes including the following: (i) response to different biotic and abiotic stresses (Khraiwesh et al. 2012; Kompelli et al. 2015); (ii) different development and protein degradation processes (Eldem et al., 2012), (iii) pathogen invasion, signal transduction etc. (Jones-Rhoades et al. 2006; Jung et al. 2009).

Simple Sequence Repeats (SSRs), also known as microsatellites are short tandem repeats of DNA sequences that are 1-6 bp long (Gupta et al. 1996; Chen et al. 2009). The SSRs are found both in prokaryotic and eukaryotic genomes (Toth et al. 2000; Katti et al. 2001). SSRs are co-dominant, and multi-allelic by nature and due to constant variation in the number of tandem repeats; they are known to be, robust, highly polymorphic (Brandstrom et al. 2008, Heesacker et al. 2008), locus-specific and co-dominant, thus becoming the markers of choice. (Gupta et al. 1996; Ni et al. 2002; Lightfoot and Iqbal, 2013; Senan et al. 2014; Wang et al. 2015 ). Previous reports show that SSRs are selectively neutral and are randomly distributed in the eukaryotic genome (Schlotterer, 2000; Schlotterer, 2004). Although many of them are found in protein coding (Madsen et al., 2000), non-coding (Riley and Krieger, 2009a, 2009b) or untranslated regions (Mondal and Ganie, 2015) of plant genome, mainstream SSRs are regularly found in non-coding regions and relatively rare in protein coding regions (Madsen et al. 2008). Furthermore, with SSRs known to have numerous applications, application of SSRs in construction of genetic maps has led to significant interest (Gupta et al. 1996; Li et al. 2002; Usdin, 2008). While SSRs aid in chromatin organization (Cuadrado and Schwarzacher, 1998), available evidence show that SSRs located in promoter regions may affect the level of gene expression (Young et al. 2000). It has been reported that they are widely considered as a hot spots for recombination (Jeffreys et al. 1998; Templeton et al. 2000). 
. Recently, SSRs have been reported in pre-miRNA sequences in some plant species. For instance, Chen et al. 2010 carried out a comprehensive analysis for the prediction of SSRs in 8,619 premiRNA sequences from 87 species, including Arthropoda, Nematoda, Platyhelminthes, Urochordata, Vertebrata, Mycetozoa, Protistate, Viridiplantae, and Viruses. In another studies, salt responsive (trait specific) miRNA-SSRs were reported in rice genome (Ganie and Mondal, 2015; Mondal and Ganie) linking them to phenotype and expression of genes. Furthermore, studies on role of transcriptional profiling of SSR specific long noncoding RNAs (lncRNAs) are studied in Banana and sugarcane which supports the hypothesis there is a major role of SSRs in non-coding genome in both small and larger noncoding elements (Cardoso-Silva et al. 2014; Yang et al. 2015). However, no study has so far been conducted to study SSRs in Pre-miRNA full length transcripts of A. thaliana, which is a model plant system with a small genome that was the first higher plant genome to be fully sequenced (The Arabidopsis Genome Initiative, 2000). Because of enormous utilities of miRNA as well as SSRs, there is a need for development of markers associated with miRNA, so that markers may be developed for traits influenced by miRNAs. Keeping this in view of the prospective development markers from the noncoding regions, we discovered miRNA-SSRs in full length genomic sequences of pre-miRNAs of A. thaliana.

\section{Methodology}

\subsection{Computational identification and discovery of miRNA-SSRs in A. thaliana genome}

A total of 325 pre-miRNAs of A. thaliana were downloaded from miRBase 21.0 (http://www.mirbase.org/) (Kozomara et al. 2014) and full length genomic transcripts representing pre-miRNA were extracted in FASTA format using BioMart-Ensembl genomes (Kasprzyk, 2011) available in EnsemblPlants (Bolser et al.2015) (see Supplementary Table 1); among 325 pre-RNAs, only 169 pre-miRNA sequences were found (see Supplementary Table 2) whose full length genomic sequences are available in EnsemblPlants. After downloading all full length premiRNA genomic transcripts from EnsemblPlants, manual annotation was done to confirm the transcripts (>1000bp + premiRNA) for the discovery of SSRs belonging to miRNA genes (i.e., promoter, 5' UTR, primRNA, or 3' UTR but not preor mature miRNA). The search for miRNA-SSRs and the designing of primers flanking miRNA-SSRs was carried out in full length premiRNA transcripts from all 5 chromosomes using BatchPrime3 v1.0 (You et al. 2008) with default parameters. A flow chart showing the pipeline used in this study is presented in Figure 1. 


\subsection{Computational Prediction of SSRs-containing miRNAs}

As earlier documented, plant miRNAs predominantly target different families of transcription factors (TFs) (Llave et al. 2002; Chen, 2004; Brodersen et al. 2008; Gupta et al. 2015; Gahlaut et al. 2016). However, subsequent studies suggested that miRNAs also target plant functional protein encoding genes, which control various physiological processes, such as root growth and development, stress responses, signal transduction, leaf morphogenesis, plant defenses, and biogenesis of sRNA (Brousse et al. 2014). Unlike in animals, miRNAs in plants identify their target mRNAs through perfect or near-perfect complementarity and initiate cleavage.

The putative target sites of SSRs-containing miRNAs were predicted by aligning the miRNA sequences either perfectly or near-perfectly binding to complementary sites on their target mRNA sequences by using homology search-based psRNATarget server (Dai and Zhao, 2011). Transcripts of SSRs-containing miRNAs were used as a query against updated version of A.thaliana transcripts available on The Arabidopsis Information Resource (TAIR) (https://www.arabidopsis.org/). Following parameters embedded in psRNATarget algorithm were used: maximum expectation: 2.0, length for complementarity scoring (hspsize): 20, target accessibility-allowed maximum energy to unpair the target site (UPE): 25.0, flanking length around target site for target accessibility analysis: 17 bp in upstream and 13 bp in downstream, Range of central mismatch leading to translation inhibition: 9-11nt.

\subsection{Prediction of genes adjacent to identified miRNA-SSRs and analysis of enriched gene ontologies (GO)}

Genes adjacent to identified novel miRNA-SSRs were manually predicted using the TAIR 9 browser embedded in windows based integrated genome browser (IGB) (Nicol et al. 2009). The criteria for manual curation was based on location of SSRs and nearby gene located on 5' untranslated region (5' UTR) and 3' untranslated region (3' UTR) sites on a particular chromosome of A. thaliana genome. Further predicted adjacent transcripts were retrieved from the EnsemblPlants (Bolser et al., 2015) in FASTA format. Arabidopsis adjacent transcripts were used as input for Gene ontology analysis using agriGO (Du et al. 2010) and REVIGO (Supek et al. 2011) server.

\section{Result and Discussion}




\subsection{Dinucleotide repeats were found to outnumber other repeats}

In the present study, 147 miRNA-SSRs were discovered among 169 pre-miRNA genomic transcripts of A. thaliana genome (Table. 1). We found that dinucleotide SSR repeats (48/147) outnumbered the other repeats; primers designed for 45 of these dinucleotide repeats while no primers were designed for the remaining three SSRs including $(\mathrm{AC})_{7}$ associated with miR164b, (AT) $)_{7}$ associated with miR165b and and (TA) 10 associated with miR832A. Ten (10) different classes of dinucleotide SSR repeats were found in all premiRNA transcripts of A.thaliana and the largest count of dinucleotide repeat was TA. (Fig.2). While trinucleotide miRNA-SSR repeats were found to be less than dinucleotide repeats, only one of 38 repeats was found with no SSR flanking primer (TTC with miR837a and SSR length 12). Nevertheless, there were 37 SSR flanking primers found to be associated with them. Within 15 different classes of trinucleotide miRNA-SSRs repeats, TTC and CTT with same number of counts formed the highest count of trinucleotide repeats (Fig.2)

The tetranucleotide miRNA-SSRs (46) were found to be more than trinucleotide repeats but less than dinucleotide repeats. Primers flanking two SSRs viz. (TTTA)n, and $(\text { TTAT })_{n}$ for miR164c and miR394a, respectively could not be designed (TTTA) $)_{n}$ repeats was most abundant among the tetranucleotide repeats in discovered miRNA-SSRs. (Fig. 2). The pentanucleotide SSRs in pre-miRNA transcripts of $A$. thaliana were least frequent. Out of the 12 of the 147 miRNA-SSRs, were pentanucleotide repeats. Primers flanking to 11 miRNASSRs were designed and no primers could be designed for, (TTGTT) ${ }_{3}$ associated with miR777a. Only eight classes of pentanucleotide SSR repeats were found in all pre-miRNA transcripts of $A$. thaliana and TTTTA was found as topmost count of pentanucleotide SSRs (Fig. 2). The hexanucleotide miRNA-SSRs were least common and these belonged to $(\text { GTTTGA })_{\mathrm{n}},(\mathrm{GGGAGG})_{\mathrm{n}},(\text { ACAAAT })_{\mathrm{n}}$, and $(\mathrm{CGTTTC})_{\mathrm{n}}$ classes to be associated with flanking primers and remarkably distributed across all 5 chromosome in A.thaliana genome (Fig. 3). The chromosomes 1 and 5 have maximum miRNA-SSRs, while chromosome 3 has minimum number of miRNA-SSRs (Fig. 3).

\subsection{Conservation of SSR loci spanning flanking regions}

The miRNA-SSR polymorphism will provide trait-related molecular markers at the specific chromosomal loci, which in turn would depend on the number of indels in the flanking regions. Whether or not they are dinucleotide repeats or compound repeats is dependent not only on variances at the each repeat unit of the sequences, but also on how they are arranged 
174 or distributed across the genome. As we observed such repeats, it would be interesting to

175 examine their locus specific polymorphism to allow their physically mapping. It would be

176 interesting to see if they can serve as unknown tagged sites which in turn would depend on

177 the presence of a particular sequence tagged region or sequence tagged sites (STS). These

178 STS' in principle can be used as potential markers.

\subsection{SSRs-containing miRNAs targeted diverse set of TFs}

On the basis of the biogenesis of miRNAs in plants, a homology search-based method was used to predict the targets for SSRs-containing miRNA in A. thaliana using psRNATarget.

The SSR-containing miRNAs were used as queries to predict potential mRNA targets in the Arabidopsis genome annotation (TAIR10). This search revealed that 90 SSR-containing miRNAs identified 698 target genes, with each SSR-containing miRNA predicting more than one gene (Table S1). Most of the SSR-containing miRNAs targeted a number of TFs families including WRKY, MADS, MYB, NAC, bHLH, AP2/EREBP, ARF etc., which play an important role in different metabolic and regulatory processes such as stress response, transcriptional regulation, signal transduction, growth, development, nutrient uptake, nutrient transport and nutrient assimilation (Table 2). The values of UPE for targeted gene ranged from 3.238 to 24.941 .

Targeted TFs could be utilized for developing next generation microsatellites, Transcription Factor Gene-Derived Microsatellite (TFGM) Markers which have potential in markerassisted genetic improvement and genotyping applications through marker assisted selection (MAS) breeding program to develop the drought/heat responsive and nutrient efficient cultivars for cereal crops (Gupta and Prasad, 2009; Kujur et al. 2013, 2014; Liu et al. 2015 ). However in plants, (TFGM) markers have only been reported in chickpea and Medicago truncatula to date (Kujur et al. 2013; Liu et al. 2015).

\subsection{Prediction of genes adjacent to identified miRNA-SSRs and GO analysis}

In order to predict the genes adjacent to SSR containing miRNAs, representing $5^{\prime}$ UTR and 3' UTR sites TAIR 9 was manually curated. Based on length and chromosomal location, a diverse set of adjacent genes were predicted both in n5' UTR and 3' UTR regions (Table. 2). Predicted adjacent transcripts revealed that SSR containing miRNAs are associated with different genes in network form, which play a pivotal role in gene regulation. However effect of miR-SSR on adjacent genes and vice- versa need to be studied in detail. 
207 To evaluate the biological significance of the adjacent genes to SSR containing miRNAs in

208 Arabidopsis it is important to have the gene ontology (GO) descriptions i.e., detailed 209 annotations of gene function, biological process it is involved, and cellular location of the 210 gene product. The potential functions were predicted by searching against GO database using 211 agriGO and REVIGO server. Predicted adjacent transcripts were subjected to singular 212 enrichment analysis (SEA) embedded in agriGO to identify enriched GOs. SEA designed to 213 identify enriched GO terms in a list form of microarray probe sets or gene identifiers 214 available in database. Finding different enriched GO terms corresponds to finding enriched 215 biological facts, and term enrichment level was judged by comparing query list to a 216 background population from which the query list is derived. In this study the background 217 query list comprised of 27,416 protein coding genes from the updated TAIR 218 (https://www.arabidopsis.org/index.jsp). Fig. 4 wholly reflects the categorization of 219 adjacent genes based on biological process, cellular component and molecular function. 220 Adjacent genes were divided into 14 GO categories. Among the adjacent gene transcripts, 221 GOs associated with response to stimulus, cellular biosynthetic process, nitrogen compound 222 metabolic process, nucleobase, nucleoside, cellular macromolecule metabolic process, protein 223 metabolic process, transport activity, RNA metabolic process, gene regulation and binding 224 (Fig.5).

225 In order to reduce the number of GO terms, enriched GO categories with false discovery 226 rates $($ FDR $)<0.05$ from AgriGO analysis were submitted to the REVIGO (REduce and 227 Visualize GO) server. Using the Uniprot (http://www.uniprot.org/) as background and the 228 default semantic similarity measure (Simrel), this analysis clearly showed that biological 229 processes associated with metabolism, localization, nitrogen regulation, regulation of 230 transcription were significantly overrepresented among the adjacent genes to SSR containing 231 miRNAs in Arabidopsis (Fig.6).

\subsection{Taking an analogy with long non-coding RNAs}

If we may consider an analogy of this keeping in view of their larger non-coding peers, viz. lncRNAs, we might expect SSRs to be mapped to the lncRNAs as well. What remains a challenge is to see if the miRNAs/lncRNAs have a coding potential of transcripts in noncoding RNA as these are associated with "unknown transcripts" which eventually are unmapped. Can the SSR-miRNAs that code for non-coding elements prove to be real candidates for understanding gene expression in plants underlying to various traits as discussed above? If it were the case, with breakthrough in genome technology in the form of 
241 clustered regulatory interspaced short palindromic repeats/CRISPR-associated protein

242 9(CRISPR-Cas9) technology (Sander and Joung, 2014; Jain, 2015), it would be interesting to

243 explore probable CRISPR loci that play a role into regulatory roles of these ncRNAs esp. the

244 smaller miRNAs (Yi et al. 2015).

\section{4. Conclusion}

246 In the present study, we discovered total 147 miRNA-SSRs from 169 pre-miRNAs representing

247 full length genomic transcripts of A. thaliana. Our result shows that all the di-, tri-, tetra-, penta

248 and hexanucleotide SSRs were located in non-coding repertoire of all the 5 chromosomes of

249 A.thaliana (Fig. 3). While dinucleotide miRNA-SSRs were found to be higher, hexanucleotide

250 miRNA-SSRs were found to be lowest repeats in the pre-miRNA transcripts. It was observed

251 that miRNA-SSRs flanking primers were larger in number for discovered miRNA-SSRs. We

252 firmly consider these candidates could be extended for experimentation for allelic variation. It

253 is important to know that these miRNA-SSRs serve as a source of highly informative molecular

254 markers and aids as a reference for marker assisted breeding in plants. We hope this first report

255 on genome-wide identification and characterization of miRNA-SSRs in A. thaliana could serve

256 as a reference for identifying more sequences from non-coding repertoire of the genomes.

257 Acknowledgments

258 AK would like to give his sincere thanks to Mr. Deepak Kumar, Secretary, IT, ST \& BT

259 Government of Uttarakhand for encouragement, suggestions and timely help. PKG was

260 awarded a National Academy of Sciences India (NASI) Senior Scientist Platinum Jubilee

261 Fellowship, and INSA Senior Scientist positions during the tenure of which this study was

262 conducted; VG was awarded a Junior Research Fellowship under the same program, and was

263 later awarded the position of SRF/ RA under a DBT project.

\section{Authors Contributions}

265 AK, AC, SKK, and VG performed the data analysis; KPS and MNVPG manually

266 crosschecked the annotation. KPS assisted AK and AC for preparing the first draft. PS, HSB

267 and PKG conceived, supervised, edited, and finalized the manuscript.

268

\section{Conflict of Interest Statement}

270 The authors declare that the research was conducted in the absence of any commercial or

271 financial relationships that could be construed as a potential conflict of interest.

\section{References}


Bartel B, Bartel DP (2003) MicroRNAs: At the root of plant development?. Plant Physiol 132:709-717

Bartel DP (2004) MicroRNAs: genomics, biogenesis, mechanism, and function. Cell 116:281-297

Bolser DM, Kerhornou A, Walts B, Kersey P (2015) Triticeae resources in Ensembl Plants. Plant Cell Physiol 56:e3

Brandstrom M, Bagshaw AT, Gemmell NJ, Ellegren H (2008) The relationship between microsatellite polymorphism and recombination hot spots in the human genome. Mol Biol Evol 25: 2579-87

Brodersen P, Sakvarelidze-Achard L, Bruun-Rasmussen M, Dunoyer P, Yamamoto YY, Sieburth L, Voinnet O (2008) Widespread translational inhibition by plant miRNAs and siRNAs. Science 320:1185-1190

Brousse C, Liu Q, Beauclair L, Deremetz A, Axtell MJ, Bouché N (2014) A noncanonicial microRNA target site. Nucleic Acids Res 42: 5270-5279

Cardoso-Silva CB, Costa EA, Mancini MC, Balsalobre TW, Canesin LE, Pinto LR, Carneiro MS, Garcia AA, de Souza AP, Vicentini R (2014) De novo assembly and transcriptome analysis of contrasting sugarcane varieties. PLoS One 9:e88462

Chen M, Tan Z, Zeng G, Peng J (2010) Comprehensive analysis of simple sequence repeats in Pre-miRNA. MolBiolEvol 27:2227-2232

Chen X (2004) A microRNA as a translational repressor of APETALA2 in Arabidopsis flower development. Science 303:2022-2025

Chen M, Tan Z, Jiang J, Li M, Chen H, Shen G, Yu R (2009) Similar distribution of simple sequence repeats in diverse completed Human Immunodeficiency Virus Type 1 genomes. FEBS Lett 583:2959-2963

Cuadrado A, Schwarzacher T (1998) The chromosomal organization of simple sequence repeats in wheat and rye genomes. Chromosoma 107:587-594

Dai X, Zhao PX (2011) psRNATarget: a plant small RNA target analysis server. Nucleic Acids Res 39: 155-159

Du Z, Zhou X, Ling Y, Zhang Z, Su Z (2010)agriGO: a GO analysis toolkit for theagricultural community. Nucleic Acids Res. 38(W): 64-70

Eldem V, Okay S, Ünver T (2013). Plant microRNAs: new players in functional genomics. Turk J Agric For 37:1-21

Gahlaut V, Jaiswal V, Kumar A, Gupta PK (2016) Transcription factors involved in drought tolerance and their possible role in developing drought tolerant cultivars with emphasis on wheat (Triticum aestivum L.). Theor Appl Genet 129: 2019-2042

Ganie SA Mondal TK (2015) Genome-wide development of novel miRNA-based microsatellite markers of rice (Oryza sativa) for genotyping applications. Mol Breeding 35:51

Gupta PK (2015) MicroRNAs and target mimics for crop improvement. Curr Sci 108: $1624-1633$

Gupta PK, Balyan HS, Sharma PC, Ramesh B (1996) Microsatellites in plants: A new class of molecular markers. Curr Sci 70:45-53

Gupta S, Prasad M (2009) Development and characterization of genic SSR markers in Medicago truncatula and their transferability in leguminous and non-leguminous species. Genome. 52: 761-771

Heesacker A, Kishore VK, Gao W, Tang S, Kolkman JM, Gingle A, Matvienko M, Kozik A, Michelmore RM, Lai Z, Rieseberg LH, Knapp SJ (2008) SSRs and INDELs mined from the sunflower EST database: abundance, polymorphisms, and cross-taxa utility. Theor Appl Genet 117:1021-1029 
Jain M (2015) Function genomics of abiotic stress tolerance in plants: a CRISPR approach. Front Plant Sci 6:375

Jeffreys AJ, Murray J, Neumann R (1998) High-resolution mapping of crossovers in human sperm defines a minisatellite associated recombination hotspot. Mol Cell 2: 267-273

Jones-Rhoades MW, Bartel DP, Bartel, B (2006) MicroRNAs and their regulatory roles in plants. Annu Rev Plant Biol 57: 19-53

Jung JH, Seo PJ, Park CM (2009) MicroRNA biogenesis and function in higher plants. Plant Biotechnol Rep 3: 111-126

Kasprzyk A (2011) BioMart: driving a paradigm change in biological data management. Database (Oxford) 13:2011:bar049

Katti MV, Ranjekar PK, Gupta VS (2001). Differential distribution of simple sequence repeats in eukaryotic genome sequences. MolBiolEvol 18: 1161-1167

Khraiwesh B, Zhu JK, Zhu J (2012) Role of miRNAs and siRNAs in biotic and abiotic stress responses in plants. Biochem Biophys Acta 1819:137-148

Kompelli SK, Kompelli VSP, Enjala C, Suravajhala P (2015) Genome-wide identification of miRNAs in pigeonpea (Cajanus cajan L.) Aust J Crop Sci 9:215-222

Kozomara A, Griffiths-Jones S (2014) miRBase: annotating high confidence microRNAs using deep sequencing data. Nucleic Acids Res 42(D):68-73

Kujur A, Bajaj D, Saxena M, Tripathi S, Upadhyaya HD, Gowda CL, Singh S, Tyagi A, Jain M, Parida S (2014) An efficient and cost-effective approach for genic microsatellite marker-based large-scale trait association mapping: Identification of candidate genes for seed weight in chickpea. Mol Breed 34: 241-265

Kujur A, Bajaj D, Saxena MS, Tripathi S, Upadhaya HD, Gowada CL, Singh S, Jain M, Tyagi AK, Parida SK (2013) Functionally relevant microsatellite markers from chickpea transcription factor genes efficient genotyping applications and trait association mapping. DNA Res 20: 355-374

Li YC, Korol AB, Fahima T, Beiles A, Nevo E (2002) Microsatellites: genomic distribution, putative functions and mutational mechanisms: a review. MolEcol $11: 2453-2465$

Lightfoot DA, Iqbal MJ (2013) Molecular mapping and breeding with microsatellite markers. Methods MolBiol 1006: 297-317

Liu W, Jia X, Liu Z, Zhang Z, Wang Y, Liu Z, Xie W (2015) Development and Characterization of Transcription Factor Gene-Derived Microsatellite(TFGM) Markers in Medicagotruncatula and Their Transferability in Leguminous and Non Leguminous Species. Molecules 20:8759-8771

Llave C, Xie Z, Kasschau KD, Carrington JC (2002) Cleavage of scarecrow-like mRNA targets directed by a class of Arabidopsis miRNAs. Science 297: 2053-2056

Madsen BE, Villesen P, Wiuf C (2008) Short tandem repeats in human exons: a target for disease mutations. BMC Genomics 9:410

Mondal TK, Ganie SA (2014) Identification and characterization of salt responsive miRNA-SSR markers in rice (Oryza sativa). Gene 535:204-209

Ni J, Colowit PM, Mackill DJ (2002) Evaluation of genetic diversity in rice subspecies using microsatellite markers. Crop Sci 42: 601-607

Nicol JW, Helt GA, Blanchard SG Jr, Raja A, Loraine AE (2009) The Integrated Genome Browser (IGB): free software for distribution and exploration of genome-scale datasets. Bioinformatics 25:2730-1

Riley DE, Krieger JN (2009a) Embryonic nervous system genes predominate in searches for dinucleotide simple sequence repeats flanked by conserved sequences. Gene 429:74-79 
Riley DE, Krieger JN (2009b) UTR dinucleotide simple sequence repeat evolution exhibits recurring patterns including regulatory sequence motif replacements. Gene 429:80-86
Sander
$\mathrm{JD}$,
Joung
JK
(2014)
CRISPR-Cas systems for editing, regulating and targeting genomes. Nat Biotechnol 32:347-55

Schlotterer C (2000) Evolutionary dynamics of microsatellite DNA. Chromosoma 109: 5844-5849

Schlötterer C (2004) The evolution of molecular markers-Just a matter of fashion? Nat Rev Genet 5: 63-69

Senan S, Kizhakayil D, Sasikumar B, Sheeja TE (2014) Methods for Development of Microsatellite Markers: An Overview. Not Sci Biol 6:1-13

Supek F, Bosnjak M, Skunca N, Smuc T (2011) REVIGO summarizes and visualizes long lists of gene ontology terms. PloS One 6:e21800

Templeton AR, Clark AG, Weiss KM, Nickerson DA, Boerwinkle E, Sing CF (2000) Recombinational and mutational hot spots within the human lipoprotein lipase gene. Am J Hum Genet 66:69-83

The Arabidopsis Genome Initiative (2000) Analysis of the genome sequence of the flowering plant Arabidopsis thaliana. Nature 408:796-815

Toth G, Gaspari Z, Jurka J (2000) Microsatellites in different eukaryotic genomes: survey and analysis. Genome Res 10: 967-981

Usdin K (2008) The biological effects of simple tandem repeats: lessons from the repeat expansion diseases. Genome Res 18:1011-1019

Wang Y, Yang C, Jin Q, Zhou D, Wang S, Yu Y, Yang L (2015) Genome-wide distribution comparative and composition analysis of the SSRs in Poaceae. BMC Genetics 16:18

Yang QS, Gao J, He WD, Dou TX, Ding LJ, Wu JH, Li CY, Peng XX, Zhang S, Yi GJ (2015) Comparative transcriptomics analysis reveals difference of key gene expression between banana and plantain in response to cold stress. BMC Genomics 16:446

Yi X, Zhang Z, Ling Y, Xu W, Su Z (2015) PNRD: a plant non-coding RNA database. Nucleic Acids Res 43:D982-989

You FM, Huo N, Gu YQ, Luo MC, Ma Y, Hane D, Lazo GR, Dvorak J, Anderson OD (2008) BatchPrimer3: a high throughput web application for PCR and sequencing primer design. BMC Bioinformatics 9:253

Young ET, Sloan JS, van Riper K (2000) Trinucleotide repeats are clustered in regulatory genes in Saccharomyces cerevisiae. Genetics 154:1053-1068

\section{Legend}

Figure1. Pipeline used for discovery of miRNA-SSRs in A. thaliana.

Figure 2 .Incidence and number of di, tri, tetra, and pentanucleotide miRNA-SSRs.

Figure 3. Chromosomal locations of discovered miRNA-SSRs in A.thaliana geneome.

Figure 4. GO classifications of adjacent genes to SSR containing miRNAs.

Figure 5. GO analysis of adjacent genes to SSR containing miRNAs: box reflects the GO term number, the p-value in parenthesis, and GO term. The first pair of numerals shows the number of adjacent genes in the input list associated with that GO term and the number of genes in the input list. The second pair of numerals represents the number of genes associated 
419

420

421

422

423

424

425

426

427

428

429

430

431

with the particular GO term in the TAIR database and the total number of Arabidopsis genes with GO annotations in the TAIR database. The box colours indicates levels of statistical significance with yellow $=0.05$; orange $=\mathrm{e}-05$ and red $=\mathrm{e}-09$.

Figure 6. GO analysis of adjacent genes to SSR containing miRNAs using REVIGO: The scatter plot represents the cluster representatives (terms remaining after reducing redundancy) in a two-dimensional space derived by applying multi-dimensional scaling to a matrix of GO terms semantic similarities. Bubble color indicates the p-value for the false discovery rates derived from the AgriGO analysis. The circle size represents the frequency of the GO term in the uniprot database (more general terms are represented by larger size bubbles).

\section{Fig 1.}

Extract A. thaliana premiRNAs from miRBase 21.0 database

Manual screening of $A$. thaliana full length miRNA genomic transcripts available at EnsemblPlants

Downloaded all full length miRNA genomic transcripts from EnsemblPlants in FASTA format using BioMart program

Manual analysis to confirm the transcript (>1000bp + premiRNA) used to discover the SSRs belongs to miRNA gene (i.e. promoters, 5'UTR, Pri-, or 3' UTR but not pre or mature miRNAl

Discovered total 147 miRNA-SSRs and designing flanking primers from all 5 chromosomes using BatchPrimer3v1.0 (on by default parameters)

Prediction of targets for SSRs-containing miRNAs using psRNATarget server

Fig 2. 
bioRxiv preprint doi: https://doi.org/10.1101/203851; this version posted November 2, 2017. The copyright holder for this preprint (which was not certified by peer review) is the author/funder, who has granted bioRxiv a license to display the preprint in perpetuity. It is made available under aCC-BY-NC-ND 4.0 International license.

438

439

\section{No. of SSRs Repeats}

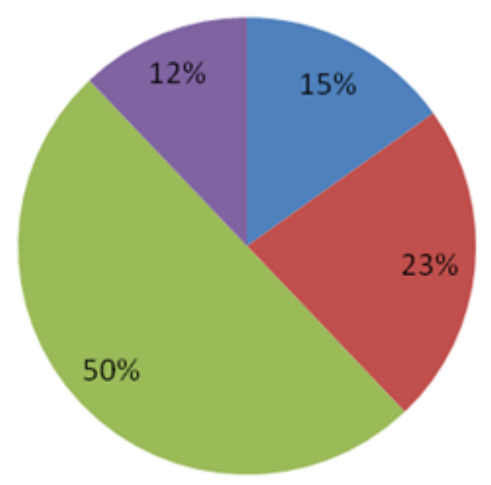

Dinucleotides

- Trinucleotides

Tetranucleotides

Pentanucleotides

440

441

442

Fig 3.

443

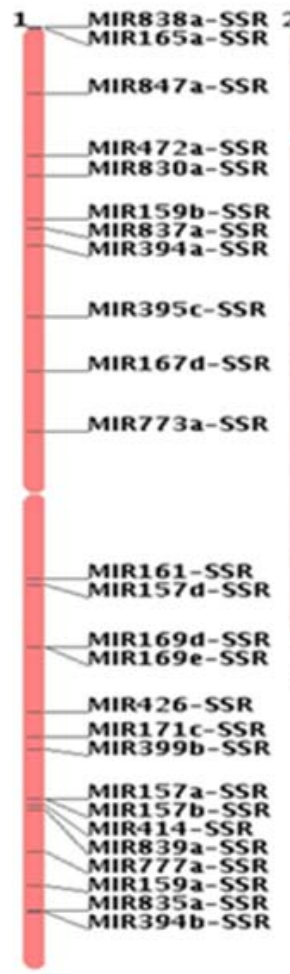

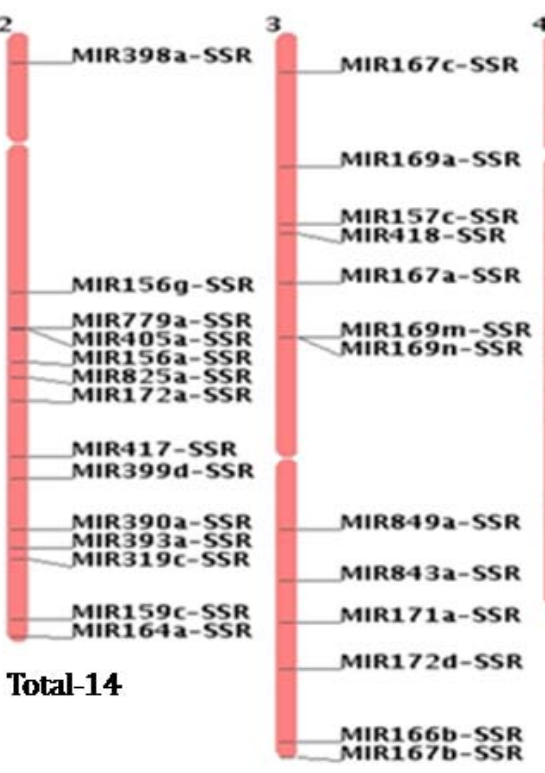

Total-13

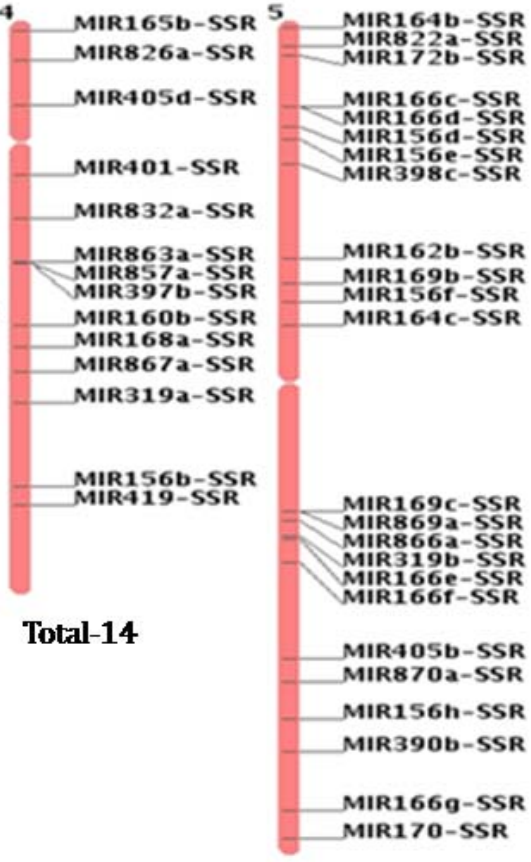

Total-25

Total-26 
bioRxiv preprint doi: https://doi.org/10.1101/203851; this version posted November 2, 2017. The copyright holder for this preprint (which was not certified by peer review) is the author/funder, who has granted bioRxiv a license to display the preprint in perpetuity. It is made available under aCC-BY-NC-ND 4.0 International license.

Fig 4.
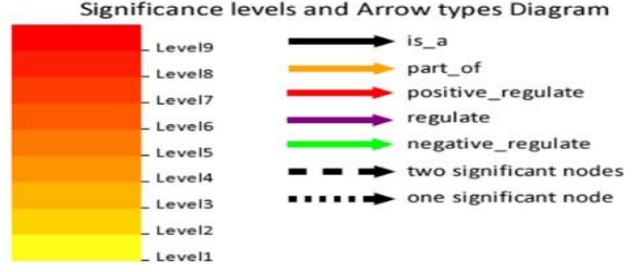

s
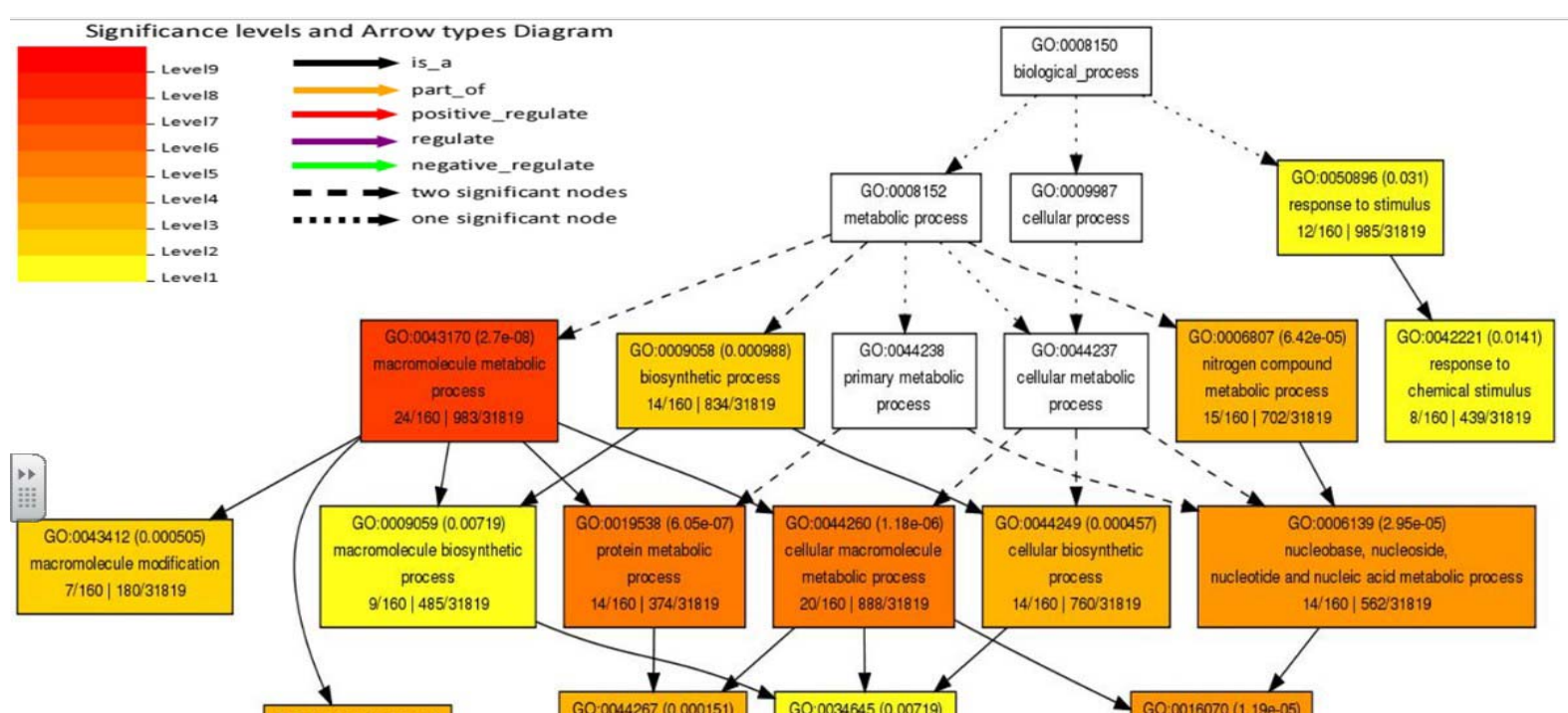
bioRxiv preprint doi: https://doi.org/10.1101/203851; this version posted November 2, 2017. The copyright holder for this preprint (which was not certified by peer review) is the author/funder, who has granted bioRxiv a license to display the preprint in perpetuity. It is made available under aCC-BY-NC-ND 4.0 International license.

Fig 5.

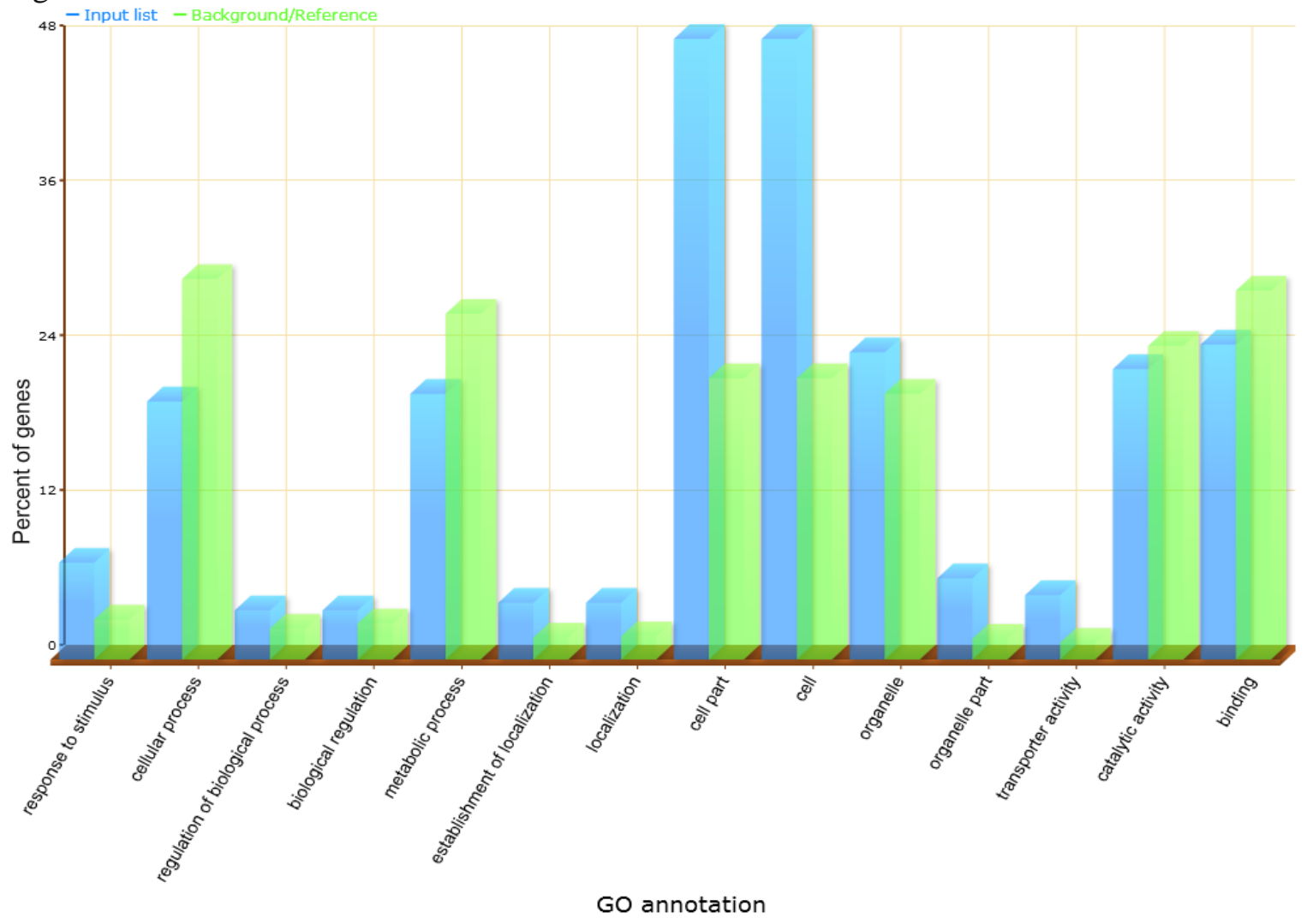


bioRxiv preprint doi: https://doi.org/10.1101/203851; this version posted November 2, 2017. The copyright holder for this preprint (which was not certified by peer review) is the author/funder, who has granted bioRxiv a license to display the preprint in perpetuity. It is made available under aCC-BY-NC-ND 4.0 International license.

504

505

506

507

508

509

510

511

512

513

514

515

516

517

518

519

520

521

522

523

524

525

526

527

528

529
Fig 6.

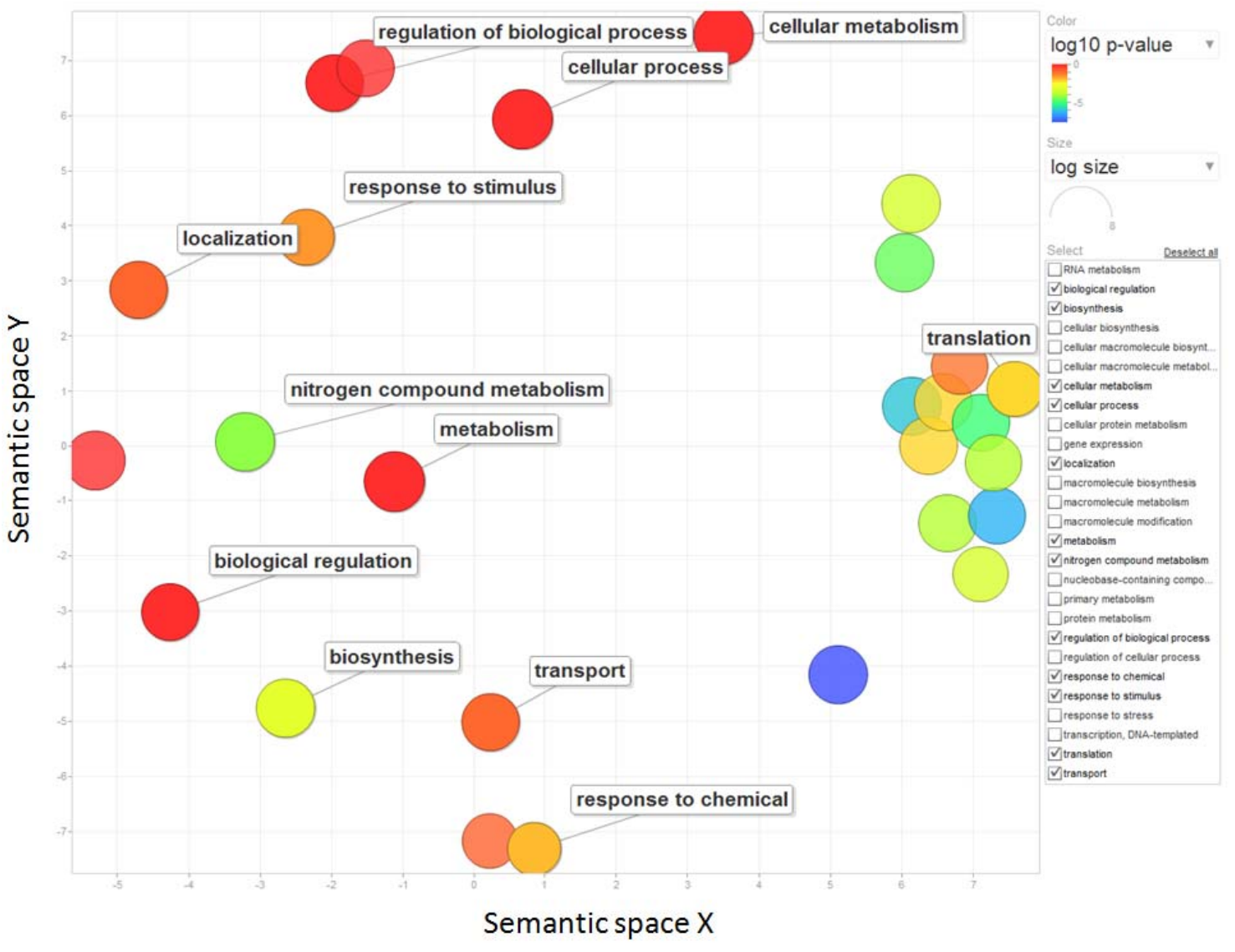


530

531 Table 1. Designed flanking primers for discovered miRNA-SSRs using BatchPrimer3 server.

\begin{tabular}{|c|c|c|c|c|c|}
\hline \multirow[t]{2}{*}{ MIRNA } & \multirow[t]{2}{*}{ Motif } & \multicolumn{2}{|c|}{ Primer Sequence } & \multirow{3}{*}{$\begin{array}{c}\mathbf{T m} \\
\left({ }^{0} \mathrm{C}\right) \\
55\end{array}$} & \multirow{3}{*}{$\begin{array}{c}\begin{array}{c}\text { Product } \\
\text { Size }\end{array} \\
154\end{array}$} \\
\hline & & Forward & Reverse & & \\
\hline MIR156a & $(\mathrm{TCTT})_{3}$ & ACAAGAGCCATAAAGAAAGGT & AGGGTTTTTGTCTAAATCGAG & & \\
\hline MIR156b & $(\mathrm{CT})_{11}$ & САCСТCTCTTTCTGTCAGTTG & ACACATCACTAGCAAAAGTGC & 55 & 140 \\
\hline \multirow[t]{2}{*}{ MIR156d } & $(\mathrm{TTC})_{6}$ & TCTCCATCATCTCTGTTTCAC & GGCTGCTTTACTTCTCTCTCT & 55 & 154 \\
\hline & $(\mathrm{GAGT})_{3}$ & TGTTGGATTCATTCTTCATTC & AAGGAGATAAACTCAGAATTGC & 55 & 176 \\
\hline MIR156e & $(\mathrm{TC})_{7}$ & TTGAAGCTATGTGTGCTTACTC & ACTTTGATCCGTTTGATGATA & 55 & 153 \\
\hline \multirow[t]{2}{*}{ MIR156f } & $(\mathrm{CT})_{9}$ & GAAGCTATGTGTGCTCACTCT & GTAAAACCAAAAGAATGGATG & 54 & 139 \\
\hline & $(\mathrm{AT})_{8}$ & АСТCTCTTCTTGTCTCCTGCT & AACCATACACAGAGACGTTTG & 55 & 153 \\
\hline \multirow[t]{3}{*}{ MIR156g } & $(\mathrm{GAT})_{4}$ & AAACGTAGCTAGTGGTCAGTG & AAACGTAGCTAGTGGTCAGTG & 55 & 152 \\
\hline & $(\text { TATC })_{3}$ & АСТCTCTTCTTGTCTCCTGCT & AACCATACACAGAGACGTTTG & 55 & 153 \\
\hline & $(\mathrm{CATG})_{3}$ & АCTCTCTTCTTGTCTCCTGCT & AACCATACACAGAGACGTTTG & 55 & 153 \\
\hline MIR156h & $(\mathrm{TTC})_{5}$ & TCATCCTCTTCGCTATAAATG & AGGTTGTGCTCTCTTTCTTCT & 55 & 144 \\
\hline \multirow{2}{*}{ MIR157a } & $(\mathrm{TCA})_{4}$ & TTCGTTGCTCTCTATGTGTCT & TTCGTTGCTCTCTATGTGTCT & 55 & 161 \\
\hline & $(\mathrm{AAGT})_{3}$ & GTTCGTAGTCTTCTCAAATCG & AACCATCAAACCTTATGGAAT & 55 & 170 \\
\hline MIR157b & $(\mathrm{TCA})_{4}$ & TAGCTGTCCTCTATGCGTCTA & TCAAGAACTTGATTAAACACCA & 55 & 187 \\
\hline \multirow{2}{*}{ MIR157c } & $(\mathrm{TA})_{8}$ & TATTTTCCCTTTGTCACTTCA & GTCAACAACCAАCATCACTCT & 55 & 150 \\
\hline & $(\mathrm{AT})_{22}$ & TTTGGTAACCTGATCTCCATA & CCAAАCTATCAAACCAAACTG & 54 & 137 \\
\hline \multirow[t]{2}{*}{ MIR157d } & $(\mathrm{TA})_{13}$ & TATGCTTCTGTCATCACCTTT & АСТTТТСТСАСАССААААСАА & 55 & 156 \\
\hline & $(\mathrm{AAAG})_{3}$ & GATGCTATGCAAAACAGACAC & GGTGATGACAGAAGCATAGAG & 55 & 151 \\
\hline MIR159a & $(\mathrm{TC})_{6}$ & ATTTCTTCCAAAACATGACG & CAAAAACACCAAAAGAGGTAA & 55 & 158 \\
\hline \multirow[t]{2}{*}{ MIR159b } & $(\mathrm{TC})_{7}$ & TAATGGCTTCACTCTTCTTTG & CTACTCAAGATCCATCATCCA & 55 & 153 \\
\hline & $(\mathrm{AAT})_{4}$ & GACAATAAGATTTACTGCCAAA & AAAGAGCATCAACCCTAGTCT & 54 & 141 \\
\hline \multirow[t]{2}{*}{ MIR159c } & $(\mathrm{CAT})_{4}$ & ATAATCGTCCCAAGGAGTAGA & AAACTATGGAAAGAGGGAGAA & 55 & 141 \\
\hline & $(\mathrm{AAAT})_{4}$ & САСССТАACCGTATCTCTCTC & TCTACTCCTTGGGACGATTAT & 55 & 190 \\
\hline MIR160b & $(\mathrm{TA})_{6}$ & CCAATCATATTTAAGGGTTCC & TTGGTCATGCTTGACTACTCT & 55 & 150 \\
\hline MIR161 & $(\mathrm{AGA})_{4}$ & CTTTGTTTGAGATTGCATCAT & TGACTACCAGTCTACCACTATGT & 55 & 158 \\
\hline \multirow{2}{*}{ MIR162b } & $(\text { TTTA })_{3}$ & GTTTGTTCATCAACCGATTT & TCGATTCTTGCTTTTGTAAAC & 55 & 153 \\
\hline & $(\text { TTGT })_{3}$ & GATTCGATAAAGTCTTCTCAGC & TGATCTGTTACCCAAAACAAT & 55 & 173 \\
\hline
\end{tabular}




\begin{tabular}{|c|c|c|c|c|c|}
\hline MIR164a & $(\mathrm{CA})_{9}$ & TTGCCTTACGTAAAACACACT & TGAGAACTTTGGTTATGGAAA & 38 & 137 \\
\hline & $(\mathrm{AC})_{7}$ & No SSR flanking primer found & & & \\
\hline & $(\mathrm{TA})_{7}$ & GGAATCACGTTTTCAAATATC & AAGTGCGAGTGTTGTTTATGT & 54 & 149 \\
\hline & $(\mathrm{TC})_{10}$ & ATCATACCCCCAAGGTAACTA & ATTCTCTCCGACCACATAACT & 55 & 153 \\
\hline 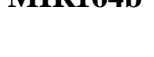 & $(\mathrm{TG})_{6}$ & AGTTATGTGGTCGGAGAGAAT & TCATCCATATCATCACACTCA & 55 & 165 \\
\hline & $(\mathrm{ACAT})_{3}$ & ATCATACCCCCAAGGTAACTA & ATTCTCTCCGACCACATAACT & 55 & 153 \\
\hline & $(\mathrm{TACG})_{3}$ & GAGGAAGTAGATACCCTCTGC & GATCAAGATGCGTGATCATA & 54 & 135 \\
\hline MIR164c & $(\text { TTTA })_{4}$ & No-SSR flanking primer found & & & \\
\hline MOP & $(\mathrm{AT})_{7}$ & ACTATGAAACCTTCACGCATA & CCTCATCATAACACCATCATC & 54 & 154 \\
\hline & $(\mathrm{CT})_{7}$ & CCTCATCATAACACCATCATC & TAATATCCTCGATCCAGACAA & 55 & 157 \\
\hline & $(\mathrm{AT})_{7}$ & No-SSR flanking primer found & & & \\
\hline & $(\mathrm{TC})_{7}$ & ACGACTTATTTCAGCCTTCTT & GCAGCTCAATCTTATGTGAGT & 55 & 155 \\
\hline & $(\mathrm{TC})_{14}$ & TTTGGCTCTCTCTCCACTTAC & GGCTAAGATCAAGGAAGAGAA & 56 & 146 \\
\hline & $(\mathrm{AAG})_{5}$ & TTCTCTTCCTTGATCTTAGCC & AGAAAAATCCCTCTTTAAATCC & 55 & 159 \\
\hline & $(\mathrm{TC})_{6}$ & CACGTCACAATTCACATCTTA & TTAAGTCTCGTCGTTGTCTTC & 54 & 161 \\
\hline MIR166c & $(\mathrm{TCT})_{4}$ & GTGGTCATTTGTGCCTCTAT & CCACGTTATCAAGAAGAGAAA & 55 & 150 \\
\hline & $(\mathrm{CTTT})_{3}$ & CACTCGAATTAATTTGGAAGA & GGTCGCAAGATAGAACAAATA & 55 & 150 \\
\hline MIR166d & $(\mathrm{CTT})_{7}$ & AATATTCGCCTCACACATAGA & TCAATCTACCGATCTTCTTCA & 55 & 141 \\
\hline MIR166e & $(\mathrm{TC})_{8}$ & СССТСТСТTСТTТTCATCATT & CTCAAAAGGAAAAGCTTCACT & 55 & 152 \\
\hline MIR166f & $(\mathrm{GAT})_{5}$ & GTCTTTCTGAGCCAAAAGTTC & CTTGAAGATTGAGAAGCAAAA & 56 & 146 \\
\hline MIR166g & $(\mathrm{CTT})_{5}$ & TAGGGCTTAGATCTTTTGTCC & AACCCTAAATCGCTTCACTAT & 55 & 162 \\
\hline MIR167a & $(\mathrm{AAAG})_{4}$ & CCAAAAACCAAGAATAAGAAGA & CCAAAAACCAAGAATAAGAAGA & 55 & 162 \\
\hline & $(\mathrm{GA})_{11}$ & TGGAGTCAAACTAAGAATGGA & TATATCTCCACCACCTGTGAC & 55 & 173 \\
\hline & $(\mathrm{CT})_{7}$ & TCACAGGTGGTGGAGATATAG & TTAAAGAAGCCTGAAACAGTG & 55 & 150 \\
\hline MIR167c & $(\mathrm{AG})_{7}$ & AGCATGATCTTGTCTTCCTCT & TCTCCTTCATGCTACAATCAT & 55 & 158 \\
\hline & $(\mathrm{AGA})_{7}$ & GAGAGAGACTAGGTCATGCTG & TTCATGAGATCCTCTTTCTGA & 54 & 129 \\
\hline MUD167 & $(\mathrm{TG})_{7}$ & AACAAGGATCTGTGTAACGTG & GAAAAATGCTCAGCTTGATAA & 55 & 152 \\
\hline & $(\mathrm{GT})_{7}$ & ATGTATGTGGTGTGTGTGTCA & GAGGGATCGTAAAAGTTAAGG & 55 & 157 \\
\hline & $(\mathrm{CTT})_{4}$ & AGTGTGAAAGCGAAAATCTCT & TAATGGGGAAATGAGGTTTAT & 56 & 157 \\
\hline & $(\mathrm{AATA})_{3}$ & CACGTGCTTCTCAAAAAGATA & GTCTCTTTTCACCCGAGAGT & 55 & 186 \\
\hline
\end{tabular}




\begin{tabular}{|c|c|c|c|c|c|}
\hline MIR169b & $(\mathrm{TTCA})_{3}$ & TGAACATATTTCTGGCAAGTT & CTCATACGGTCGATGTTAATC & 55 & 134 \\
\hline \multirow{2}{*}{ MIR169c } & $(\text { TTTA })_{3}$ & TTGAGATGCTAAAGTAGAGCAA & CGAAGTTGAATTTTGACATTG & 55 & 178 \\
\hline & $(\text { TTAT })_{4}$ & GGCTCAACATGTAGGAAAGTA & GATTGGAGCAAACTAAACTCTT & 55 & 167 \\
\hline MIR169d & $(\mathrm{CGAT})_{3}$ & TAATACCGAAAACCCAAAACT & CCACCTGTCGTACTTTTCTTA & 55 & 162 \\
\hline \multirow{2}{*}{ MIR169e } & $(\mathrm{ATG})_{5}$ & TCATCATGAGTTAGGGTTTTG & TCATCATGAGTTAGGGTTTTG & 55 & 140 \\
\hline & $(\mathrm{ATC})_{4}$ & AAAGATTCCTCССТTCTTTTT & GCTGCAAGTACAAGTGTTGA & 55 & 160 \\
\hline MIR169m & $(\mathrm{AT})_{14}$ & AGATGGACATGACAAGAAAAA & ATCCATGTTCTTCCACAATC & 55 & 165 \\
\hline \multirow{2}{*}{ MIR169n } & $(\mathrm{TA})_{6}$ & AAACACGTCTAAAGTTGCATT & GTCGGTTCATTCACTAAATTG & 55 & 144 \\
\hline & $(\mathrm{AT})_{14}$ & AGATGGACATGACAAGAAAAA & AGATGGACATGACAAGAAAAA & 55 & 165 \\
\hline MIR170 & $(\mathrm{CTT})_{4}$ & GTGCATTGAGAGTAGCAGAGT & GGACTCTCTCGGAAACATAGT & 55 & 157 \\
\hline \multirow{2}{*}{ MIR171a } & $(\mathrm{AG})_{6}$ & TTGAGGTTTTGTAAAAAGCAG & ATAAATTTTGAGGGAATCTCG & 55 & 139 \\
\hline & $(\mathrm{AGAA})_{4}$ & GCAGAGAAAGAGAGAGAGAGG & ATCGATGAAGATGCTTTGTAA & 55 & 142 \\
\hline \multirow[t]{2}{*}{ MIR171c } & $(\mathrm{TCAC})_{3}$ & GCCCAATGTTATAAAGGGTAG & GACACCTTCAATTTCGTGATA & 56 & 172 \\
\hline & $(\mathrm{TC})_{11}$ & ACAGTCACATCTCTTACTGTGC & TTGGAAGCCATATATTAACCA & 55 & 118 \\
\hline \multirow[t]{2}{*}{ MIR172a } & $(\mathrm{CT})_{7}$ & TGATTCACTCTCCACAAAGTT & АCCTACCTGAAGAAGATCTGG & 55 & 142 \\
\hline & $(\text { GTTTGA })_{5}$ & TGAAGGTACGAGTTTCTAGTGTC & CGGAAATTAGTCTTCCATTTT & 55 & 182 \\
\hline MIR172b & $(\mathrm{TTC})_{4}$ & TCTTATGACGTAAAAGGACCA & TTCGATCTCTATTTTCTTGGA & 55 & 171 \\
\hline \multirow{4}{*}{ MIR172d } & $(\mathrm{CT})_{9}$ & GTATCTTCGATTACGATGTGC & GGAAGAGATTTAGGGTGAAGA & 55 & 155 \\
\hline & $(\mathrm{TA})_{6}$ & TCAGAAATCCAGATCCTCATA & ATCATTCATCATCGTTTTGTC & 55 & 163 \\
\hline & $(\mathrm{CT})_{6}$ & АТСТАССАТСССТTTTCTACG & AGAGATGGGAAAAGAAGATGA & 55 & 144 \\
\hline & $(\mathrm{ATAC})_{3}$ & АТCTACCATCССТTTTCTACG & AGAGATGGGAAAAGAAGATGA & 55 & 144 \\
\hline \multirow[t]{2}{*}{ MIR319a } & $(\mathrm{ATAC})_{3}$ & GTTCCAAACGCTCTATCTCTT & CGAAAAACCATGATTTAGAAG & 55 & 154 \\
\hline & $(\mathrm{AATG})_{3}$ & CCAAAATTCAAACTAGACTCG & TAGTGGATCAAGCATGTTTTT & 54 & 157 \\
\hline MIR319b & $(\mathrm{AATG})_{3}$ & TCCACTCATGGAGTAATATGTG & CTTCAGTCCAAGCATAGAGAA & 55 & 146 \\
\hline \multirow{2}{*}{ MIR319c } & $(\mathrm{AAT})_{5}$ & TCTTCGGTTATGACGACTATG & AATAAATCAGGGAGGAAAATG & 55 & 148 \\
\hline & $(\mathrm{ATA})_{4}$ & TCTTCGGTTATGACGACTATG & AATAAATCAGGGAGGAAAATG & 55 & 148 \\
\hline MIR390a & $(\mathrm{ATTA})_{3}$ & GTCGGGTAAGTTTCATCTGTA & GTCGGGTAAGTTTCATCTGTA & 54 & 144 \\
\hline \multirow[t]{3}{*}{ MIR390b } & $(\mathrm{TA})_{7}$ & TGTAATATGGGGACACTTAGC & CATCCATAGGTATGCATCTTC & 54. & 164 \\
\hline & $(\mathrm{TA})_{14}$ & GCTATTTCCGAAAACTTTTGT & CAAACTACCAAGTAAGCATGAA & 55 & 155 \\
\hline & $(\mathrm{AAG})_{4}$ & CAACCTTGTATCTCAAGCCTA & AAATCCAATGAAGAAGAAAGC & 55 & 162 \\
\hline
\end{tabular}




\begin{tabular}{|c|c|c|c|c|c|}
\hline \multirow[t]{2}{*}{ MIR393a } & $(\mathrm{AAAT})_{4}$ & CGTCTGGTTTACTAGCTCCAT & GATCGTGTTCCTCTTGATTTT & 56 & 149 \\
\hline & $(\text { TTAT })_{5}$ & No SSR-flanking primers found! & & & \\
\hline MIR394b & $(\mathrm{TC})_{7}$ & TGCCTCTTTCTCAАTCTCATA & CGAATGTAACATCGAGAGGTA & 55 & 149 \\
\hline MIR395c & $(\text { TTTGG) })_{4}$ & TTTGTTTACACCCAAACCTAA & AATGCGAGTGACAGTCATTAT & 55 & 133 \\
\hline MIR398a & $(\mathrm{TCT})_{4}$ & CСAAAACCAACTAAAACTGAA & GCTTTGGAATAAACAGAGGAG & 55 & 134 \\
\hline MIR398c & $(\mathrm{CTT})_{4}$ & GTACGAGTATCCGTAGAGCAG & AAACTCGAACCAGAACAAACT & 55 & 151 \\
\hline MIR399d & $(\mathrm{TTG})_{4}$ & AACACAATCGTCTTTCATCAC & TGGTTCTTTCTTTCTTTCCTC & 55 & 138 \\
\hline \multirow{2}{*}{ MIR399d } & $(\mathrm{TTCT})_{3}$ & TCATACGGTTCTCGAAGAATA & GCAACTCAAAATTTGTGAAAC & 55 & 146 \\
\hline & $(\mathrm{GAAA})_{3}$ & GATTCTTTCTTTCTTCTGTTGG & TAAGGAATGGTTGATGACACT & 55 & 147 \\
\hline MIR401 & $(\mathrm{TA})_{11}$ & CСAACATTCAAGATCСТTCTA & CAAGTTCCCCTTTGTTTACTC & 55 & 151 \\
\hline MIR405a & $(\mathrm{AACCC})_{3}$ & TTGTTACTAGGGGTGTCAAAA & CCCATCAAATGAAATGAGTTA & 55 & 144 \\
\hline MIR405b & $(\text { GTTGG })_{3}$ & CCCATCAAATGAAATGAGTTA & TTAAGTTCATTCCTGTGGGTA & 55 & 157 \\
\hline MIR405d & $(\mathrm{TTC})_{4}$ & TAATGTTTATCTCCGACTCCA & GCATCCTTAGACCAGTCTTTA & 55 & 145 \\
\hline \multirow{2}{*}{ MIR414 } & $(\mathrm{ATC})_{4}$ & TATTAGATGGTGGTGAGGATG & GATGACGATGATGATGAAGAT & 55 & 134 \\
\hline & $(\mathrm{TCA})_{6}$ & GCTTGAAGTCGAAGATAAAGA & TTGCTTCTCAACTCAAATCTC & 54 & 157 \\
\hline MIR417 & $(\mathrm{AAAT})_{3}$ & AGGTTGTACTTATGTGGTGGA & AGATAATGTAGGTGGGAGATACA & 55 & 147 \\
\hline \multirow{2}{*}{ MIR418 } & $(\mathrm{CAAA})_{5}$ & AGGTGTCAGGTTCTACACAAA & CCAATACATGTGTTAGGATTTTT & 55 & 150 \\
\hline & $(\text { TTTTA })_{3}$ & AAATACCCCAAAAAGAGACAC & AAATACCCCAAAAAGAGACAC & 55 & 146 \\
\hline MIR419 & $(\mathrm{TTGC})_{3}$ & GCTGAGGATGTTGTTATTACG & GGTTCATGACTTGTTTTCTTG & 55 & 158 \\
\hline \multirow{2}{*}{ MIR426 } & $(\mathrm{TAAA})_{4}$ & GTGGACCAAAAGACATACAAT & TGGTGTTGTTTCTTTCCTCTA & 54 & 200 \\
\hline & $(\mathrm{GGGAGG})_{3}$ & TGCAATGGATCAGTTAGAATAG & ATCGTCATGTGGACAAGTATT & 55 & 151 \\
\hline MIR472a & $(\text { TGTA })_{3}$ & AAGGGGAGTCATATTCTCATC & CAAACACCAAAACCTTACAAA & 55 & 200 \\
\hline
\end{tabular}




\begin{tabular}{|c|c|c|c|c|c|}
\hline \multirow{3}{*}{ MIR773a } & $(\mathrm{AAT})_{4}$ & TGTCTAAGAGAGTTTTTAGCAAG & GTTATTGGGCTTTTATTGGAT & 53 & 292 \\
\hline & $(\text { TTAT })_{3}$ & CTGGTACATTCATAGTTGTTGC & CAAAACTCTACTCCGTGTTTG & 55 & 151 \\
\hline & $(\text { TTGTT })_{3}$ & No-SSR flanking primer found & & & \\
\hline MIR779a & $(\text { TGTTT })_{3}$ & GTTAGCTGAGCAACCATACTT & CTCATTAAGCACAATGCTTTC & 54 & 150 \\
\hline MIR822a & $(\mathrm{TA})_{20}$ & GTTTCAGAAAGGGAAAACATT & CGAAATCGAGTTTGTTAATTC & 55 & 202 \\
\hline MIR825a & $(\mathrm{CTAT})_{3}$ & ACAGGTCAATGGTGTTAGAAA & AACTGCACAAAGTCTACAAGC & 55 & 139 \\
\hline \multirow{2}{*}{ MIR826a } & $(\mathrm{TGCA})_{3}$ & TTATTATTTGGAGCCATCAAC & GTCTGTTTCTGTGTGATTCGT & 55 & 167 \\
\hline & $(\mathrm{ACAAAT})_{3}$ & CCCTAAAGTATGGGTTCACTT & GCACATGCACATGTACAATAA & 55 & 140 \\
\hline \multirow[t]{2}{*}{ MIR830a } & $(\text { TTTTG })_{3}$ & TGACACTTGTTAAAAACTCAGC & TAGCGAGACTCTGGTGAAATA & 55 & 150 \\
\hline & $(\mathrm{TA})_{10}$ & No SSR-flanking primers found! & & & \\
\hline \multirow[t]{2}{*}{ MIR832a } & $(\mathrm{TTTG})_{3}$ & GCGTTGAGTTTAAATTTTCCT & ТАТТTТССТСТТССАТТССТС & 55 & 149 \\
\hline & $(\mathrm{CGTTTC})_{3}$ & AAAAATCGTTTCTCATTTCC & ССТСАТССТТСТААСАТТGTG & 53 & 146 \\
\hline \multirow[t]{2}{*}{ MIR835a } & $(\mathrm{TTG})_{4}$ & TTATCTAAATCCGTCGTCGT & AAAATTTTCGATCCTGGTG & 55 & 152 \\
\hline & $(\mathrm{TA})_{9}$ & TCTACAGAGGATGGAAAGTCA & ACGAACAAGAAACTGATGAAA & 55 & 157 \\
\hline \multirow[t]{2}{*}{ MIR837a } & $(\mathrm{TTC})_{4}$ & No SSR flanking primer found & & & \\
\hline & $(\mathrm{TAAA})_{3}$ & TGGAAAAACATGAGGACTTTA & AACATGAAAGAAACAGATCCA & 55 & 210 \\
\hline MIR838a & $(\mathrm{TA})_{7}$ & ATGTTACTCGCTGTTCAACTC & TCAAGGCTTCAAGAATCTACA & 55 & 152 \\
\hline MIR839a & $(\mathrm{CTCA})_{3}$ & CAACTTCTCGGTTGATGTTTA & ATGCTACTCTTTCTGCTCACA & 55 & 165 \\
\hline MIR843a & $(\mathrm{AGA})_{4}$ & ATTAAACCAGCAGTGAAACAA & TGAAGAAGCTAAAGGTTGGAT & 55 & 153 \\
\hline MIR847a & $(\mathrm{TCT})_{7}$ & GACTCGAAGGTTGAAGAAAGT & TATGGTGACGGATTTACAAAG & 55 & 151 \\
\hline MIR849a & $(\text { TTTA })_{3}$ & AGCTTTTCTTCTGGGTTATGT & TGGTCTAGTAGTTGTCCAATCA & 55 & 165 \\
\hline MIR857a & $(\text { TTTTA })_{3}$ & ATGAAGAAAACACCCAAAAAG & TCTCCACAATAGTCACGCTAC & 56 & 148 \\
\hline MIR863a & $(\text { TATT })_{3}$ & GGGGAAAACTCTTTCTTATGT & CTCTCAATCGCATTGGTATAA & 54 & 213 \\
\hline \multirow{2}{*}{ MIR866a } & $(\mathrm{ATC})_{4}$ & TTTTCTCTTTCGACTCCTCTT & TCAAGGGTGTGAATCATTTAG & 55 & 155 \\
\hline & $(\mathrm{ATTA})_{3}$ & AACATCAAACCAACTTTCTGA & TCAATTGTCTTTTCGAATCTC & 55 & 166 \\
\hline \multirow{2}{*}{ MIR867a } & $(\mathrm{AAG})_{4}$ & CAAAACTGATTTAAAGTTTGTGG & TGTCTATTGGGCTTACAAGAA & 56 & 152 \\
\hline & $(\mathrm{GAA})_{4}$ & AAAAGAAGAAGAAGAACGATG & TGATATTGGGCATTTGTCTAT & 55 & 127 \\
\hline \multirow{2}{*}{ MIR869a } & $(\mathrm{AT})_{10}$ & TAACAGTATTCGTGGGAAAAA & СТTAТCCAАCAАCТАCCACCA & 55 & 149 \\
\hline & $(\mathrm{AT})_{6}$ & TGGTGGTAGTTGTTGGATAAG & AGGAGTTTTCTCAAGAAGGTG & 55 & 153 \\
\hline & $(\mathrm{TCT})_{4}$ & AAACAATCGATCAACATCATC & CAAAAATTTCAAATCCCATC & 55 & 154 \\
\hline
\end{tabular}


bioRxiv preprint doi: https://doi.org/10.1101/203851; this version posted November 2, 2017. The copyright holder for this preprint (which was not certified by peer review) is the author/funder, who has granted bioRxiv a license to display the preprint in perpetuity. It is made available under aCC-BY-NC-ND 4.0 International license.

$(\mathrm{AGA})_{4}$ 
Table 2. Genes located adjacent to the miRNA-SSRs.

\begin{tabular}{|c|c|c|c|c|c|c|}
\hline miRNA & $\begin{array}{l}\text { Accession } \\
\text { Number }\end{array}$ & Chr no & 5' UTR genes & Gene Description & 3' UTR genes & Gene Description \\
\hline MIR838a & AT1G01046 & Chr 1 & AT1G01040 & Encodes a Dicer homolog. & AT1G01070 & Nodulin MtN21-like transporter family protein \\
\hline MIR165a & AT1G01183 & Chr 1 & AT1G01180 & $\begin{array}{l}\text { S-adenosyl-L-methionine-dependent } \\
\text { methyltransferases superfamily } \\
\text { protein }\end{array}$ & AT1G01210 & DNA-directed RNA polymerase \\
\hline MIR847a & AT1G07051 & Chr 1 & AT1G07050 & CCT motif family protein & AT1G07060 & Unknown protein \\
\hline MIR472a & AT1G12294 & Chr 1 & AT1G12290 & $\begin{array}{l}\text { Disease resistance protein (CC-NBS- } \\
\text { LRR class) family }\end{array}$ & AT1G12300 & $\begin{array}{l}\text { Tetratricopeptide repeat (TPR)-like superfamily } \\
\text { protein }\end{array}$ \\
\hline MIR830a & AT1G14071 & Chr 1 & AT1G14060 & GCK domain-containing protein & AT1G14090 & Pseudogene \\
\hline MIR159b & AT1G18075 & Chr 1 & AT1G18070 & $\begin{array}{l}\text { Translation elongation factor } \\
\text { EF1A/initiation factor IF2gamma } \\
\text { family protein }\end{array}$ & AT1G18080 & $\begin{array}{l}\text { Encodes the Arabidopsis thaliana homolog of the } \\
\text { tobacco WD- } 40 \text { repeat ArcA gene }\end{array}$ \\
\hline MIR837a & AT1G18879 & Chr 1 & AT1G18871 & $\begin{array}{l}\text { Unknown protein; LOCATED IN: } \\
\text { endomembrane system }\end{array}$ & AT1G18880 & NITRATE TRANSPORTER \\
\hline MIR394a & AT1G20375 & Chr 1 & AT1G20370 & Pseudouridine synthase family protein & AT1G20380 & Prolyl oligopeptidase family protein \\
\hline MIR395c & AT1G26985 & Chr 1 & AT1G26976 & $\begin{array}{l}\text { Unknown protein; FUNCTIONS IN: } \\
\text { molecular_function unknown }\end{array}$ & AT1G26990 & Transposable element gene \\
\hline MIR167d & AT1G31173 & Chr 1 & AT1G31166 & Transposable element gene & AT1G31175 & Unknown protein \\
\hline MIR773a & AT1G35501 & Chr 1 & AT1G35500 & Unknown protein & AT1G35510 & O-fucosyltransferase family protein \\
\hline MIR161 & AT1G48267 & Chr 1 & AT1G48260 & $\begin{array}{l}\text { Encodes a member of the SNF1- } \\
\text { related kinase (SnRK) gene family }\end{array}$ & AT1G48270 & Unknown protein \\
\hline
\end{tabular}




\begin{tabular}{|c|c|c|c|c|c|c|}
\hline MIR157d & AT1G48742 & Chr 1 & AT1G48740 & $\begin{array}{l}\text { 2-oxoglutarate (2OG) and Fe(II)- } \\
\text { dependent oxygenase superfamily } \\
\text { protein }\end{array}$ & AT1G48745 & Unknown protein \\
\hline MIR169d & AT1G53683 & Chr 1 & AT1G53660 & $\begin{array}{l}\text { Nucleotide/sugar transporter family } \\
\text { protein }\end{array}$ & AT1G53687 & MICRORNA169E \\
\hline MIR169e & AT1G53687 & Chr 1 & AT1G53683 & $\begin{array}{l}\text { Encodes a microRNA that targets } \\
\text { several HAP2 family members }\end{array}$ & AT1G53690 & $\begin{array}{l}\text { Protein of unknown function that is homologous to } \\
\text { At5g41010 }\end{array}$ \\
\hline MIR426 & AT1G60025 & Chr 1 & AT1G60020 & Transposable element gene & AT1G60050 & Nodulin MtN21-like transporter family protein \\
\hline MIR171c & AT1G62035 & Chr 1 & AT1G62030 & $\begin{array}{l}\text { Cysteine/Histidine-rich } \mathrm{C} 1 \text { domain } \\
\text { family protein }\end{array}$ & AT1G62045 & $\begin{array}{l}\text { BEST Arabidopsis thaliana protein match is: } \\
\text { ankyrin repeat family protein (TAIR:AT1G11740.1) }\end{array}$ \\
\hline MIR399b & AT1G63005 & Chr 1 & AT1G62981 & $\begin{array}{l}\text { Protein of unknown function } \\
\text { (DUF1191) }\end{array}$ & AT1G63010 & $\begin{array}{l}\text { Major Facilitator Superfamily with SPX } \\
\text { (SYG1/Pho81/XPR1) domain-containing protein }\end{array}$ \\
\hline MIR157a & AT1G66783 & Chr 1 & AT1G66780 & MATE efflux family protein & AT1G66790 & Unknown protein \\
\hline MIR157b & AT1G66795 & Chr 1 & AT1G66790 & Unknown protein & AT1G66800 & Unknown protein \\
\hline MIR414 & AT1G67195 & Chr 1 & AT1G67190 & F-box/RNI-like superfamily protein & AT1G67200 & Pseudogene \\
\hline MIR839a & AT1G67481 & Chr 1 & AT1G67480 & $\begin{array}{l}\text { Galactose oxidase/kelch repeat } \\
\text { superfamily protein }\end{array}$ & AT1G67510 & Leucine-rich repeat protein kinase family protein \\
\hline MIR777a & AT1G70645 & Chr 1 & AT1G70640 & $\begin{array}{l}\text { Octicosapeptide/Phox/Bem1p (PB1) } \\
\text { domain-containing }\end{array}$ & AT1G70650 & Ran BP2/NZF zinc finger-like superfamily protein \\
\hline MIR159a & AT1G73687 & Chr 1 & AT1G73680 & Encodes an alpha dioxygenase & AT1G73690 & CYCLIN-DEPENDENT KINASE D1 \\
\hline MIR835a & AT1G76062 & Chr 1 & AT1G76050 & Pseudouridine synthase family protein & AT1G76065 & LYR family of $\mathrm{Fe} / \mathrm{S}$ cluster biogenesis protein \\
\hline MIR394b & AT1G76135 & Chr 1 & AT1G76120 & Pseudouridine synthase family protein & AT1G76140 & Prolyl oligopeptidase family protein \\
\hline MIR398a & AT2G03445 & Chr 2 & AT2G03430 & Ankyrin repeat family protein & AT2G03460 & Galactose oxidase/kelch repeat superfamily protein \\
\hline MIR156g & AT2G19425 & Chr 2 & AT2G19420 & Unknown protein & AT2G19415 & Hydroxyproline-rich glycoprotein family protein \\
\hline
\end{tabular}




\begin{tabular}{|c|c|c|c|c|c|c|}
\hline MIR779a & AT2G22496 & Chr 2 & AT2G22482 & Unknown protein & AT2G22510 & Polynucleotidyl transferase \\
\hline MIR405a & AT2G22668 & Chr 2 & N/A & N/A & N/A & N/A \\
\hline MIR156a & AT2G25095 & Chr 2 & AT2G25090 & $\begin{array}{l}\text { Encodes a member of the SNF1- } \\
\text { related kinase (SnRK) gene family }\end{array}$ & AT2G25100 & Polynucleotidyl transferase \\
\hline MIR825a & AT2G26211 & Chr 2 & AT2G26210 & Ankyrin repeat family protein & AT2G26215 & Transposable_element_gene \\
\hline MIR172a & AT2G28056 & Chr 2 & AT2G28053 & Transposable element gene & AT2G28060 & $\begin{array}{l}\text { 5'-AMP-activated protein kinase beta-2 subunit } \\
\text { protein }\end{array}$ \\
\hline MIR417 & AT2G32273 & Chr 2 & AT2G32240 & Unknown protein & AT2G32275 & Expressed protein \\
\hline MIR399d & AT2G34202 & Chr 2 & AT2G34200 & $\begin{array}{l}\text { RING/FYVE/PHD zinc finger } \\
\text { superfamily protein }\end{array}$ & AT2G34210 & Transcription elongation factor Spt5 \\
\hline MIR390a & AT2G38325 & Chr 2 & AT2G38304 & Unknown protein & AT2G38330 & MATE efflux family protein \\
\hline MIR393a & AT2G39885 & Chr 2 & AT2G39870 & Unknown protein & AT2G39900 & Encodes a member of the Arabidopsis LIM proteins \\
\hline MIR319c & AT2G40805 & Chr 2 & AT2G40802 & Unknown protein & AT2G40815 & $\begin{array}{l}\text { Calcium-dependent lipid-binding (CaLB domain) } \\
\text { family protein }\end{array}$ \\
\hline MIR159c & AT2G46255 & Chr 2 & AT2G46250 & Myosin heavy chain-related & AT2G46260 & Encodes a member of the Arabidopsis LIM proteins \\
\hline MIR164a & AT2G47585 & Chr 2 & AT2G47570 & $\begin{array}{l}\text { Ribosomal protein } \mathrm{L} 18 \mathrm{e} / \mathrm{L} 15 \\
\text { superfamily protein }\end{array}$ & AT2G47610 & $\begin{array}{l}\text { Ribosomal protein L7Ae/L30e/S12e/Gadd45 family } \\
\text { protein }\end{array}$ \\
\hline MIR167c & AT3G04765 & Chr 3 & AT3G04760 & $\begin{array}{l}\text { Pentatricopeptide repeat (PPR-like) } \\
\text { superfamily protein }\end{array}$ & AT3G04780 & Thioredoxin-like protein \\
\hline MIR169a & AT3G13405 & Chr 3 & AT3G13403 & $\begin{array}{l}\text { Encodes a defensin-like (DEFL) } \\
\text { family protein. }\end{array}$ & AT3G13410 & Unknown protein \\
\hline MIR157c & AT3G18217 & Chr 3 & AT3G18215 & Protein of unknown function, DUF599 & AT3G18220 & LIPID PHOSPHATE PHOSPHATASE 4 \\
\hline MIR418 & AT3G18895 & Chr 3 & AT3G18890 & $\begin{array}{l}\text { NAD(P)-binding Rossmann-fold } \\
\text { superfamily protein }\end{array}$ & AT3G18900 & FUNCTIONS IN: molecular_function unknown \\
\hline
\end{tabular}




\begin{tabular}{|c|c|c|c|c|c|c|}
\hline MIR167a & AT3G22886 & Chr 3 & AT3G22870 & $\begin{array}{l}\text { F-box and associated interaction } \\
\text { domains-containing protein }\end{array}$ & AT3G22910 & $\begin{array}{l}\text { ATPase E1-E2 type family protein / haloacid } \\
\text { dehalogenase-like hydrolase family protein }\end{array}$ \\
\hline MIR169m & AT3G26818 & Chr 3 & AT3G26816 & $\begin{array}{l}\text { Encodes a microRNA that targets } \\
\text { several HAP2 family members }\end{array}$ & AT3G26819 & MICRORNA169N \\
\hline MIR169n & AT3G26819 & Chr 3 & AT3G26818 & $\begin{array}{l}\text { Encodes a microRNA that targets } \\
\text { several HAP2 family members }\end{array}$ & AT3G26820 & Esterase/lipase/thioesterase family protein \\
\hline MIR849a & AT3G44444 & Chr 3 & AT3G44440 & unknown protein & AT3G44450 & unknown protein \\
\hline MIR843a & AT3G48057 & Chr 3 & AT3G48050 & 'SHUTTLE' IN CHINESE, SUO & AT3G48058 & pseudogene of Rac-like GTP-binding protein \\
\hline MIR171a & AT3G51375 & Chr 3 & AT3G51370 & Protein phosphatase $2 \mathrm{C}$ family protein & AT3G51390 & DHHC-type zinc finger family protein \\
\hline MIR172d & AT3G55512 & Chr 3 & AT3G55490 & GINS complex protein & AT3G55520 & $\begin{array}{l}\text { FKBP-like peptidyl-prolyl cis-trans isomerase } \\
\text { family protein }\end{array}$ \\
\hline MIR166b & AT3G61897 & Chr 3 & AT3G61870 & unknown protein & AT3G61898 & unknown protein \\
\hline MIR167b & AT3G63375 & Chr 3 & AT3G63360 & $\begin{array}{l}\text { Encodes a defensin-like (DEFL) } \\
\text { family protein. }\end{array}$ & AT3G63380 & $\begin{array}{l}\text { ATPase E1-E2 type family protein / haloacid } \\
\text { dehalogenase-like hydrolase family protein }\end{array}$ \\
\hline MIR165b & AT4G00885 & Chr 4 & AT4G00880 & $\begin{array}{l}\text { SAUR-like auxin-responsive protein } \\
\text { family }\end{array}$ & AT4G00890 & $\begin{array}{l}\text { Encodes a putative glycosyl hydrolase family } 10 \\
\text { protein (xylanase). }\end{array}$ \\
\hline MIR826a & AT4G03039 & Chr 4 & AT4G03030 & $\begin{array}{l}\text { Galactose oxidase/kelch repeat } \\
\text { superfamily protein }\end{array}$ & AT4G03038 & Unknown gene \\
\hline MIR405d & AT4G05508 & Chr 4 & N/A & N/A & N/A & N/A \\
\hline MIR401 & AT4G08116 & Chr 4 & N/A & N/A & N/A & N/A \\
\hline MIR832a & AT4G10345 & Chr 4 & AT4G10330 & Glycine-rich protein & AT4G10360 & TRAM \\
\hline MIR863a & AT4G13494 & Chr 4 & AT4G13495 & Unknown gene & AT4G13500 & Unknown protein \\
\hline MIR857a & AT4G13554 & Chr 4 & AT4G13550 & Triglyceride lipases & AT4G13555 & MICRORNA397B \\
\hline
\end{tabular}




\begin{tabular}{|c|c|c|c|c|c|c|}
\hline MIR397b & AT4G13555 & Chr 4 & AT4G13554 & $\begin{array}{l}\text { Encodes a microRNA that targets a } \\
\text { Laccase family member }\end{array}$ & AT4G13575 & unknown protein \\
\hline MIR160b & AT4G17788 & Chr 4 & AT4G17780 & $\begin{array}{l}\text { F-box and associated interaction } \\
\text { domains-containing protein }\end{array}$ & AT4G17790 & SNARE associated Golgi protein family \\
\hline MIR168a & AT4G19395 & Chr 4 & AT4G19390 & $\begin{array}{l}\text { Uncharacterised protein family } \\
\text { (UPF0114) }\end{array}$ & AT4G19400 & Profilin family protein \\
\hline MIR867a & AT4G21362 & Chr 4 & AT4G21360 & Transposable element gene & AT4G21363 & transposable element gene \\
\hline MIR319a & AT4G23713 & Chr 4 & AT4G23690 & $\begin{array}{l}\text { Encodes a homodimeric all-beta } \\
\text { dirigent protein in the superfamily of } \\
\text { calycins }\end{array}$ & AT4G23720 & Protein of unknown function (DUF1191) \\
\hline MIR156b & AT4G30972 & Chr 4 & AT4G30970 & Unknown protein & AT4G30975 & Unknown gene \\
\hline MIR419 & AT4G32445 & Chr 4 & AT4G32440 & Plant Tudor-like RNA-binding protein & AT4G32450 & Pentatricopeptide repeat (PPR) superfamily protein \\
\hline MIR164b & AT5G01747 & Chr 5 & AT5G01740 & $\begin{array}{l}\text { Nuclear transport factor } 2 \text { (NTF2) } \\
\text { family protein }\end{array}$ & AT5G01750 & Protein of unknown function (DUF567) \\
\hline MIR822a & AT5G03552 & Chr 5 & AT5G03550 & TRAF-like family protein & AT5G03555 & NUCLEOBASE CATION SYMPORTER 1 \\
\hline MIR172b & AT5G04275 & Chr 5 & AT5G04270 & DHHC-type zinc finger family protein & AT5G04280 & ATRZ-1C \\
\hline MIR166c & AT5G08712 & Chr 5 & AT5G08710 & $\begin{array}{l}\text { Regulator of Chr condensation } \\
\text { (RCC1) family protein }\end{array}$ & AT5G08720 & $\begin{array}{l}\text { CONTAINS InterPro DOMAIN/s: Streptomyces } \\
\text { cyclase/dehydrase (InterPro:IPR005031) }\end{array}$ \\
\hline MIR166d & AT5G08717 & Chr 5 & AT5G08710 & $\begin{array}{l}\text { Regulator of Chr condensation } \\
\text { (RCC1) family protein }\end{array}$ & AT5G08720 & $\begin{array}{l}\text { CONTAINS InterPro DOMAIN/s: Streptomyces } \\
\text { cyclase/dehydrase (InterPro:IPR005031) }\end{array}$ \\
\hline MIR156d & AT5G10945 & Chr 5 & AT5G10946 & Unknown protein & AT5G10950 & Tudor/PWWP/MBT superfamily protein \\
\hline MIR156e & AT5G11977 & Chr 5 & AT5G11970 & $\begin{array}{l}\text { Protein of unknown function } \\
\text { (DUF3511) }\end{array}$ & AT5G11980 & $\begin{array}{l}\text { Conserved oligomeric Golgi complex component- } \\
\text { related / COG complex component-related }\end{array}$ \\
\hline MIR398c & AT5G14565 & Chr 5 & AT5G14560 & Unknown protein & AT5G14580 & polyribonucleotide nucleotidyltransferase \\
\hline
\end{tabular}




\begin{tabular}{|c|c|c|c|c|c|c|}
\hline MIR162b & AT5G23065 & Chr 5 & AT5G23035 & $\begin{array}{l}\text { Encodes a defensin-like (DEFL) } \\
\text { family protein. }\end{array}$ & AT5G23070 & Thymidine kinase \\
\hline MIR169b & AT5G24825 & Chr 5 & AT5G24820 & $\begin{array}{l}\text { Eukaryotic aspartyl protease family } \\
\text { protein }\end{array}$ & AT5G24830 & $\begin{array}{l}\text { Tetratricopeptide repeat (TPR)-like superfamily } \\
\text { protein }\end{array}$ \\
\hline MIR156f & AT5G26147 & Chr 5 & AT5G26140 & LONELY GUY 9 (LOG9) & AT5G26146 & Potential natural antisense gene \\
\hline MIR164c & AT5G27807 & Chr 5 & AT5G27800 & $\begin{array}{l}\text { Class II aminoacyl-tRNA and biotin } \\
\text { synthetases superfamily protein }\end{array}$ & AT5G27810 & MADS-box transcription factor family protein \\
\hline MIR169c & AT5G39635 & Chr 5 & AT5G39630 & $\begin{array}{l}\text { Vesicle transport v-SNARE family } \\
\text { protein }\end{array}$ & AT5G39640 & Putative endonuclease or glycosyl hydrolase \\
\hline MIR869a & AT5G39693 & Chr 5 & AT5G39670 & $\begin{array}{l}\text { Calcium-binding EF-hand family } \\
\text { protein }\end{array}$ & AT5G39730 & AIG2-like (avirulence induced gene) family protein \\
\hline MIR866a & AT5G40384 & Chr 5 & AT5G40382 & $\begin{array}{l}\text { Cytochrome } \mathrm{c} \text { oxidase subunit } \mathrm{Vc} \\
\text { family protein }\end{array}$ & AT5G40400 & Pentatricopeptide repeat (PPR) superfamily protein \\
\hline MIR319b & AT5G41663 & Chr 5 & AT5G41660 & Unknown protein & AT5G41670 & 6-phosphogluconate dehydrogenase family protein \\
\hline MIR166e & AT5G41905 & Chr 5 & AT5G41900 & $\begin{array}{l}\text { alpha/beta-Hydrolases superfamily } \\
\text { protein }\end{array}$ & AT5G41908 & Unknown protein \\
\hline MIR166f & AT5G43603 & Chr 5 & AT5G43590 & $\begin{array}{l}\text { Acyl transferase/acyl } \\
\text { hydrolase/lysophospholipase } \\
\text { superfamily protein }\end{array}$ & AT5G43620 & Pre-mRNA cleavage complex II \\
\hline MIR405b & AT5G50717 & Chr 5 & N/A & N/A & N/A & N/A \\
\hline MIR870a & AT5G52797 & Chr 5 & AT5G52790 & $\begin{array}{l}\text { FUNCTIONS IN: molecular_function } \\
\text { unknown }\end{array}$ & AT5G52780 & Protein of unknown function (DUF3464) \\
\hline MIR156h & AT5G55835 & Chr 5 & AT5G55830 & $\begin{array}{l}\text { Concanavalin A-like lectin protein } \\
\text { kinase family protein }\end{array}$ & AT5G55840 & Pentatricopeptide repeat (PPR) superfamily protein \\
\hline MIR390b & AT5G58465 & Chr 5 & AT5G58450 & $\begin{array}{l}\text { Tetratricopeptide repeat (TPR)-like } \\
\text { superfamily protein }\end{array}$ & AT5G58480 & O-Glycosyl hydrolases family 17 protein \\
\hline
\end{tabular}




\begin{tabular}{|l|l|l|l|l|l|l|}
\hline MIR166g & AT5G63715 & Chr 5 & AT5G63710 & $\begin{array}{l}\text { Leucine-rich repeat protein kinase } \\
\text { family protein }\end{array}$ & AT5G63720 & KOKOPELLI, KPL \\
\hline MIR170 & AT5G66045 & Chr 5 & AT5G66010 & $\begin{array}{l}\text { RNA-binding (RRM/RBD/RNP } \\
\text { motifs) family protein }\end{array}$ & AT5G66050 & Wound-responsive family protein \\
\hline
\end{tabular}


bioRxiv preprint doi: https://doi.org/10.1101/203851; this version posted November 2, 2017. The copyright holder for this preprint (which was not certified by peer review) is the author/funder, who has granted bioRxiv a license to display the preprint in perpetuity. It is made available under aCC-BY-NC-ND 4.0 International license.

534 